\title{
Peptide-secreting tumours with special reference to the pancreas
}

An exciting frontier of expanding medical knowledge is that which relates the secretion of humoral substances to tumours. A massive literature has accumulated in the last decade which bears witness to the existence of a number of situations in which neoplasia, or occasionally hyperplasia, of certain endocrine organs are associated with the secretion into the circulation of such quantities of agents which have pharmacologically demonstrable activity, and produce comparable degrees of physiological disturbance, as to constitute a risk to life. It has become clear that the variety of subjective and objective phenomena experienced by the patient and observed by the clinical scientist is a function of the multiplicity of biologically active substances elaborated and secreted. These effects tend to form clinically identifiable constellations.

With incomplete understanding of the relation between cause and effect in individual cases, it is inevitable that these constellations have been described as separate syndromes often bearing the names of the authors first directing attention to them. The complexity of the normal endocrine systems encourages the arbitrary separation of entities even where authors have recognized that physiological and clinical components of different syndromes overlapped. There is a continued need for vigilant clinical observations and also for pharmacological and physiological studies of individual patients which, by exposing the mechanisms in the abnormal, not only promise benefit to the patients for whom the risk to life is high, but will expand our understanding of the normal. Recognition comes to the prepared mind.

The first description of functioning carcinoma of the islet cells of the pancreas included nephrolithiasis and intractable peptic ulceration. ${ }^{1}$ This is now appreciable as reflecting a disturbance of physiology beyond the overproduction of insulin to which the authors gave their whole attention. Likewise in the first descriptions of intractable peptic ulceration accompanying an insulinoma, ${ }^{2,3}$ the possible significance of a relationship between the pancreas and the stomach was lost. In the instance of the 'insulinoma' described by Ström, ${ }^{3}$ the history and pathology was, in fact, not that of a typical beta cell adenoma and the patient at no time had hypoglycaemia. It is to the credit of Zollinger and Ellison $^{4}$ that they had the wit to gather the evidence of these and other experiences, including their own, and so to trigger enormous interest at least in the relationship of the pancreas to the stomach. Despite the subsequent surge of enquiry, more remains to be known than is already discovered.

A legion of syndromes is now evident which relates the secretion of humoral substances to tumours and in which many features are held 
in common. Thus far, the most important of these is that the substances elaborated by tumours, or by hyperplasia, in endocrine organs are polypeptides and it was this that prompted the use of peptide-secreting adenomata as a practical group terminology. ${ }^{5} \mathrm{~A}$ difficulty arises, however, that in extracts from certain tumours, and sometimes in excess in the circulation, substances have been found which are amines, sterols, and even hydroxy-fatty acids. We shall have to learn how to determine in a given situation whether all agents extractable from tissue, or present in excess in the circulation, are the primary elaborations of the cells composing the tumours, and when they represent the result of excessive activity of otherwise structurally normal secretory tissue in target organs, under the stimulus of polypeptides. An alternative consideration is the development of a feedback phenomenon ${ }^{6}$ to a central source of potential pluriglandular stimulation such, for example, as might be provided by that leader of the endocrine orchestra, the pituitary. ${ }^{7,8}$

Recently, within a single month in one journal, appeared a series of case reports which illustrate this theme. Of two diarrhoea problems, one was due to a neural crest tumour in which the tissue concentration of prostaglandin F2 alpha was grossly excessive, and the other to an alpha-cell pancreatic tumour, in the blood of which patient prostaglandin E2 was circulating in excess. ${ }^{9}$ A case of intractable constipation was related to a secreting suprarenal phaeochromocytoma and the complaint was controlled by blocking the dopamine link from tyrosine with alpha-methyl-tyrosine. ${ }^{10}$ In the blood of a myasthenic polyuric patient with an adrenal carcinoma, plasma corticosterone levels reached 50 times normal values. ${ }^{11}$ A hypoglycaemic myasthenic patient with diarrhoea and a mixed cell pancreatic adenoma had an excess in the blood of insulin-like, glucagon-like, and gastrin-like activity. ${ }^{12}$

Another whole spectrum of humoral-dependent clinical syndromes is, on the other hand, related to malignant disease which is not arising in tissues normally possessing secretory function. Thus, as examples are the associations of hepatoma with hypercalcaemia, hypoglycaemia, and polycythaemia, ${ }^{13}$ chorion carcinoma and hydatidiform mole with hyperthyroidism, ${ }^{14}$ and precocious puberty with hepatoblastomata. ${ }^{15}$ The list is already long and is well reviewed by Lipsett. ${ }^{16} \mathrm{He}$ underlined the significance of the production of humoral substances by well differentiated tumours which suggests in such circumstances the assumption by the neoplastic cell of new enzymatic characteristics. Lipsett suggested that neoplasia might modify a repressor activity built into normal cells which thus allows the unmasking of new coding instructions on the DNA molecule with which all are potentially equipped. But in most situations of peptide-elaborating tumours, it may be significant that there is a common embryological link through the particular germ cell layer of origin of secretogenic parent tissue. Adenomata arising in duodenum, pancreas, ileum, bronchus, thyroid, and pituitary are linked by the embryological relationship to the endoderm of the primitive coelomic duct. 
The list of substances thus far extractable from tumours, or demonstrated in excess in the circulation, are pharmacologically identifiable in all cases, physiologically demonstrable in many, and chemically identified in some instances. The list includes gastrin, ${ }^{17,18}$ corticotrophin, ${ }^{19}$ parathormone, ${ }^{20}$ calcitonin, ${ }^{21}$ 'secretin' ${ }^{22}$ catecholamines, ${ }^{23}$ hydroxytryptophan and its metabolites, ${ }^{24,25}$ kinins, ${ }^{26}$ glucagon, ${ }^{27}$ antidiuretic hormone, ${ }^{28}$ insulin, ${ }^{29}$ thyroid-stimulating substance, ${ }^{30}$ growth hormone, ${ }^{31}$ corticosterone, ${ }^{11}$ and prostaglandins. ${ }^{9}$

It is, however, clear that in the natural history of the disorder in any one subject with a secreting adenoma there may appear unpredictable variations in the clinical presentation and that these have sometimes been shown to be accompanied by variation, both in the nature and in the quantity of the humoral agents elaborated. In explaining this phenomenon certain difficulties arise. In association with what may appear to be a tumour of homogeneous cellular composition may be the simultaneous, or sequential, production of several of the substances listed above. ${ }^{12,32}$ A patient may simultaneously or during different episodes show such features as the flushing and borborygmi associated with the secreting carcinoid state, the disturbance of consciousness identified with hyperinsulinism, a profound non-steatorrhoeic electrolytelosing choleraic diarrhoea possibly due to excess secretin production (vide infra), the intractable peptic ulceration resulting from excess circulating gastrin, and recurrent nephrolithiasis with hypercalcaemia of hyperparathyroid or other origin. ${ }^{33}$ But many other permutations of clinical and biochemical abnormalities have been described.

Does this variable behaviour indicate that a single cell is capable of elaborating a number of substances of differing chemical structure, because there exists a variety of enzyme systems within its border? Or are individual cells capable of undergoing enzyme mutations, so that, while some cells are producing one peptide others are producing another? Or is the whole phenomenon one of chance on a basis of the enormous productivity of these cells? It has been calculated that a single liver cell may elaborate 6,000 molecules of albumin per second. Assuming a distortion of the enzyme template by a neoplastic process, a ribbon of aminoacid sequences could be continuously churned out which by chance alone, over certain periods of time, might result in the production of a sequence with the potential for physiological activity. It is important in this context to appreciate that a sequence of only four of the aminoacids which constitute the whole gastrin molecule are adequate to produce the greater part of the total physiological effects of the whole molecule. ${ }^{34} \mathrm{Or}$ is it that in the diseased state more tnan one secretory cell may be represented in excess, just as more than one endocrine organ may be involved by either hyperplasia or tumour, or by both?

The part of the spectrum of peptide-secreting tumours which has the greatest significance for gastroenterologists is that in which an abnormality of pancreatic islet tissue is invariably present. In the 
pluriglandular disorder of multiple endocrine adenomatosis ${ }^{35}$, where tumours in any or all of the adrenals, thyroids, parathyroids, and pituitary may coexist on a recognizable familial basis ${ }^{36}$ or otherwise, the presentation at any stage in the natural history of that individual of prominent choleraic diarrhoea, or of gastric hypersecretion, or of a 'functional' achlorhydria, an intractable saga of peptic ulceration, or of a carcinoid-like state: in all these situations, the essential ingredient of the mixture proves to be a hyperplasia or tumour, benign or malignant, single or multiple, of pancreatic islet tissue. ${ }^{37}$ This may be either within or upon the pancreas, or at any of the sites at which pancreatic rests are ectopically encountered.

In the normal pancreatic islets of man it is generally agreed that at least three different cell types can be identified, the alpha as a source of glucagon, the beta as a source of insulin, and the delta cell, the function of which is uncertain. Histochemical ${ }^{38,39}$ and electron microscopy studies $^{27,40,41}$ and immunofluorescent labelling ${ }^{42}$ suggest that cells in the islets and perhaps in smaller numbers in the walls of the pancreatic ductal system, as with cells of islet tumours associated with the syndromes related to gastrin hyperproduction, are similar to those found in the deeper layers of the glandular portion of the mucosa of the normal human antrum. Disaggregation combined with electron microscopy ${ }^{41}$ suggests the presence of at least two cell types in the antral mucosa containing granular bodies suggestive of secretory function and similar in character to cell types found in some pancreatic islet tumours.

By inference it is arguable that variation in the biochemical and clinical features of the syndromes described depends upon the predominance at any given time of one or other of the cell types in a state of secretory activity. When alpha cells predominate, a glucagoninduced diabetic state may be observed. When the beta cells predominate, hyperinsulinaemia is profound, and when others, perhaps the D type, the symptoms and signs result from excessive production of gastrin. The presence in extracts from islet cell tumours which have presented with choleraic water-losing, electrolyte-losing diarrhoea of a substance capable of selectively stimulating pancreatic secretion is known, ${ }^{22,43}$ and a pancreatic secretagogue has been demonstrated in the circulating blood of another patient with this disorder. ${ }^{43}$ These recent observations may lead to the elucidation of choleraic diarrhoea and suggest that cells capable of producing secretin in excess, or alternatively promoting the excessive production of secretin from its normal source are a component of certain duodenal and pancreatic tumours or of selective islet cell hyperplasia. In one of two such cases under study in our unit, there is also present in the circulation excessive gastrin-like activity, and in both cases phases of unstimulated gastric hypersecretion of the order associated with the Zollinger-Ellison syndrome have appeared, as well as the demonstration of massive spontaneous pancreatic hypersecretion in one of them. ${ }^{44}$ 
The definitive diagnosis of a lesion as a 'gastrinoma' or a 'glucagonoma', or a 'secretinoma', as with an 'insulinoma', will depend upon the morphological identification of cells in the tumour with those in a physiologically normal organ, the determination of the presence of abnormally high levels of circulating peptide utilizing immunoassay screening, ${ }^{45}$ the bioassay proof of physiological activity, ${ }^{46}$ and finally, the extraction from the tumour or organ of material which can be chemically identified. ${ }^{47}$ Thus far, this total sequence has yet to be achieved but, apart from the cell morphology, is nearly so for the gastrinoma. With improving techniques, one could forecast the recognition of the other types and to the same degree. The tumours of heterogeneous cellular morphology present a need for screening procedures allowing for the estimation and identification of different substances. The proper monitoring of progress in management as well as in the diagnosis of cases demands multiple immunoassays in order that a change in the character of the disease due either to an alteration in the predominance of cell types, or to an altered intracellular enzyme activity of a single cell type, as discussed above, may be recognized.

Although only a minority of cases of reported tumours with diarrhoea, intractable ulceration, or carcinoid syndromes, have an apparent pluriglandular relationship, it is possible that a limiting factor is time. How many more subjects, if the disease had not been halted by surgery or death, who appear at these endpoints to have a single organ involved might not otherwise in the fullness of time have shown involvement of other glands? There are many case reports of sequential involvement of different endocrine organs, and of familial groups in which the predominance in different generations of siblings is upon different endocrine structures, which support this possibility. ${ }^{35}$

Hyperplasia of islet cells, as opposed to tumour formation, is an uncertain description, but the evidence exists ${ }^{48}$ that such a limited change in structure may cause the same grotesquely disordered physiology and resultant clinical syndromes. It is possible that in some cases hyperplasia represents a preneoplastic situation. It is sometimes difficult to distinguish hyperplasia from seedling adenomata and where one mass of islet tissue is undoubtedly neoplastic, the islets in the rest of the pancreas may show varying degrees of hyperplasia. ${ }^{6,39}$ If hyperplasia is to be accepted as adequate to induce the syndromes, then in turn it is necessary to assume an excessive trophic stimulus from some other source. $^{6}$ This could be peripheral, as with an ectopic pancreatic rest in the duodenum, or central as in such situations where the pituitary is involved.

What mechanism triggers the individual saga or is responsible for the episodicity in the natural history of any one patient? For example, a peptic ulcer history of ordinary dimensions has frequently been present for several years before there occurs a qualitative change to the intractable syndrome of the 'gastrinoma' we recognize as that described by Zollinger and Ellison. Alternatively, a similar benign history may 
lead into the malign choleraic diarrhoea or to the picture of a secreting carcinoid. The induction of an endocrine imbalance might occasionally be the culprit, for in a number of women the qualitative change has appeared to follow closely upon childbirth. ${ }^{7}$ And how to explain the shutting on and off in a particular case of the disordered physiology with its clinical counterpart? In choleraic diarrhoea achlorhydria may sometimes be an expression of extreme electrolyte imbalance, but it is not always so and has been reversed by corticosteroids ${ }^{49}$ and by removal of a benign pancreatic tumour. ${ }^{6,50}$ Similarly, consider the extraordinary hazard of laparotomy, it being a common experience that a fulminating and frequently fatal phase of the disorder may set in within days or weeks of abdominal exploration, so that either the non-specific stress of a laparotomy or the handling of intra-abdominal tissues must alter the secretory behaviour of the abnormal cells.

Secondary effects with a homeostatic influence may occur which alter the presentation of the disease. The metaplasia of the mucosal lining of the duodenum and upper small intestine ${ }^{51,52}$ in response to gastric hypersecretion, and hypertrophy of the Brunner's glands, are among the reasons why peptic ulceration associated with a gastrinoma is not infrequently located in the distal part of the duodenum or the jejunum. Another source of variation may be selectivity in the trophic effect of elaborated substances upon the cells of target organs. Thus in cases of the Zollinger-Ellison syndrome, the hyperplasia of the secretory cell mass of the stomach target may be, on the one hand, predominantly parietal cell, or on the other, pepsin cell ${ }^{53,54}$, and this may account for the fact that massive gastric acid hypersecretion is not necessarily accompanied by peptic ulceration which requires proteolytic properties in the gastric juice.

Symptoms and signs which should arouse suspicion of the presence of one of the entities in the spectrum we have considered include the following. A functioning alpha cell component (glucagonoma) may be suspect where resistant dermatitis and diabetes mellitus coexist. ${ }^{55}$ Glucagon immunoassays require technical improvement, ${ }^{56}$ and an intravenous injection of glucagon, which may normally be expected to produce a rapid rise in serum insulin and plasma glucose, may have no effect where hyperglucagonaemia already exists. ${ }^{57}$ Several cases where a gastrinoma has been the probable cause, and in other cases of the choleraic diarrhoea syndrome, have had hypercalcaemia, yet a parathyroid adenoma has not always been disclosed. It has been suggested that in this circumstance, the phenomenon represents tertiary hyperparathyroidism, triggered by the initial low serum calcium level induced by hyperglucagonaemia..$^{58}$

The clinical manifestations of excessive beta cell activity are now rarely missed but in $50 \%$ of insulinomata, where immunoassays have been done, plasma insulin levels have remained normal. The effects of prolonged fasting and of tolbutamide provocation remain more reliable in diagnosis. Levin ${ }^{57}$ has stressed the significance of a paradoxical 
diabetic glucose tolerance curve in relation to insulinomata and the complex of factors which might contribute to this, to which one may now add the effect of the often present hypokalaemia..$^{59}$

There should be little excuse in the future for missing examples of the Zollinger-Ellison syndrome due to gastrinoma with the publicity given to the clinical, radiological, and biochemical characteristics. An intractable recurrent ulceration saga should immediately raise suspicion. The high unstimulated output of gastric acid secretion easy to determine, and the increasing availability both of immunoassay screening ${ }^{45}$ and bioassay ${ }^{\mathbf{4 6 0}, 60}$ for circulating gastrin, should enable the diagnosis to be definitive before laparotomy. Selective arteriography may be of assistance. ${ }^{61}$

The indication of past or present endocrine disorders in the propositus or in relatives should alert the clinician in a patient presenting with diarrhoea or intractable dyspepsia. Choleraic diarrhoea ${ }^{62}$ is suggested by the volume and frequency of the virtually odourless stools, the profound myasthenia, and the invariable gross electrolyte disturbance. In this situation, until an immunoassay to detect excess circulating pancreatic secretagogue is developed, the resting output of the pancreatic exocrine discharge into the duodenum may be aspirated and measured, a bioassay for a circulating pancreatic secretagogue can be made, and should a tumour ultimately be located, extracts examined for the effect upon the secretion of the normal pancreatic gland.

The production of unexpected 'aberrant' hormones by islet cell tumours may result in features of the Cushing syndrome, in which the identifying features are pigmentation due to high plasma level of melanocyte-stimulating hormone, ecchymoses, impaired carbohydrate tolerance, and, in females, amenorrhoea and hirsuties, with a high plasma level of circulating corticotrophin. ${ }^{19}$ When such features develop the process tends to be rapidly progressive and may be superimposed on any of the other symptom complexes induced by other humoral substances as discussed above.

A more common example is the carcinoid picture of facial plethora with episodic flushing, abdominal colic, and borborgymi, accompanied by various disturbances of tryptophan metabolism detectable in blood and urine. ${ }^{63}$ Two of the peptide-secreting adenomata in our own series have demonstrated the clinical and biochemical phenomena of the carcinoid syndrome in association with non-carcinoid islet cell tumours of the pancreas and the carcinoid picture was superimposed upon that associated with the excessive production of gastrin. ${ }^{32}$

By choosing specified aminoacids to be labelled with an isotope for the purpose of scanning the liver and pancreas, there might in the future be an increase in our ability to detect the nature of spaceoccupying lesions in these organs, according to the peptide or peptides being currently manufactured by the tumour. Thus, when selenomethionine is the scanning agent used, a pure beta-cell lesion is likely to show up as an area of absent uptake, in view of the fact that methio- 
nine is not utilized in the manufacture of insulin. On the other hand, an increase upon the normal uptake may be expected where tumour cells are producing a methionine-containing peptide such as gastrin or secretin. ${ }^{64,65}$ Although in the case of the gastrinoma so often unremovable or with metastases, a plea has been made for total gastrectomy as the optimum mode of management, ${ }^{66}$ nevertheless the finding of single lesions may justify lesser procedures. It may be possible in the near future to monitor during the operation the effect of removal of the tumour upon the activity of a located target organ, such as by observing the gastric or pancreatic exocrine outflow during an operation before and immediately after resection of a tumour. Subsequently the patient's health may be safeguarded by serial immuno- and bioassays of the blood. Another mode of monitoring progress is by serial determinations of the resting exocrine secretions of the target organs of the stomach and pancreas. By such means and with conservative surgery it may be possible to save a number of lives which are otherwise put to greater risk by a combination of partial pancreatectomy and total gastrectomy. Even where the primary or secondary lesions cannot be removed or located, or where only hyperplasia of pancreatic islets can be demonstrated, there may still be a reasonable future for such patients, many of the conditions being extremely slow in their development or low in malignancy. There is a chance that in the future there will be developed management by the use of analogues of the peptides which by occupying the receptor sites on target organs protectively block the secreting cells from the trophic stimulus of the primary lesion. Likewise it may be possible to block by suitable suppression with antagonists, or with intervenors in the metabolic pathways, the metabolic activity which results in the production of secondary amines, hydroxy-fatty acids, and the like.

WILFRED SIRCUS

\section{REFERENCES}

${ }^{1}$ Wilder, R. M., Allan, F. N., Power, M. H., and Robertson, H. E. (1927). Carcinoma of the islands of the pancreas, hyperinsulinism and hypoglycemia. J. Amer. med. Ass., 89, 348-355.

${ }^{2}$ Wulff, H. (1949). Insulon och ulcussjukdom. Nord. Med., 41, 557-558.

${ }^{3}$ Ström, R. (1952). A case of peptic ulcer and insuloma. Acta chir. scand., 104, 252-260.

'Zollinger, R. M., and Ellison, E. H. (1955). Primary peptic ulcerations of the jejunum associated with isletcell tumors of the pancreas. Ann. Surg., 142, 709-728.

${ }^{5}$ Sircus W (1967). Peptide secreting adenomata and Zollinger-Ellison Syndrome: one of a spectrum of diseases. Med. News Mag., May, 15-17.

${ }^{6}$ Friesen, S. R. (1968). A gastric factor in the pathogenesis of the Zollinger-Ellison syndrome. Ann. Surg., $168,483-501$.

${ }^{7}$ Waddell, W. R., Leonsins, A. J., and Zuidema, G. D. (1959). Gastric secretory and other laboratory studies on two patients with Zollinger-Ellison syndrome. New Engl. J., Med. 260, 56-62.

${ }^{8}$ Rudolf, L. E., Dammin, G. F., and Moore, F. D. (1960). Intractable peptic ulcer and endocrine adenomas with pituitary amphophilic hyperplasia. Surgery, 48, 170-184.

${ }^{9}$ Sandler, M., Karim, S. M. M., and Williams, E. D. (1968). Prostaglandins in amine-peptide-secreting tumours. Lancet, 2, 1053-1055.

${ }^{10}$ Jones, N. F., Walker, G., Ruthven, C. R. J., and Sandler, M. (1968), a-methyl-p-tyrosine in the management of phaeochromocytoma. Ibid., 2, $1105-1110$.

${ }^{11}$ Fraser, R., James, V. H. T., Landon, J., Peart, W. S., Rawson, A., Giles, C. A., and McKay, A. M. (1968). Clinical and biochemical studies of a patient with a corticosterone-secreting adrenocortical tumour. Ibid., 2, 1116-1120.

${ }^{12}$ Murray-Lyon, I. M., Eddleston, A. L. W. F., Williams, R., Brown, M. Hogbin, B. M., Bennett, A., Edwards, J. C., and Taylor, K. W. (1968). Treatment of multiple-hormone-producing malignant islet-cell tumour with streptozotocin. Ibid., 2, 895-898. 
${ }^{13}$ Becker, D. J., Sternberg, M. S., and Kalser, M. H. (1963). Hepatoma associated with hypoglycemia, poly . themia, and hypercalcemia. J. Amer. med. Ass., 186, 1018-1019.

${ }^{14}$ Dowling, J., Ingbar, S. H., and Freinkel, N. (1960). Iodine metabolism in hydatidiform mole and choriocarcinoma. J. clin. Endocr., 20, 1-12.

${ }^{15}$ Hung, W., Blizzard, R. M., Migeon, C. J., Camacho, A. M., and Nyhan, W. L. (1963). Precocious puberty in a boy with hepatoma and circulating gonadotrophin. J. Paediat., 63, 895-903.

${ }^{16}$ Lipsett, M. B. (1965). Humoral syndromes associated with cancer. Cancer Res., 25, 1068-1073.

${ }^{17}$ Gregory, R. A., Tracy, H. J., French, J. M., and Sircus, W. (1960). Extraction of a gastrin-like substance from the pancreatic tumour in a case of Zollinger-Ellison syndrome. Lancet, 1, 1045-1048.

${ }^{18}$ _ Grossman, M. I., Tracy, H., Jr., and Bentley, P. H. (1967). Nature of the gastric secretagogue in ZollingerEllison tumours. Ibid., 2, 543-544.

${ }^{19}$ Liddle, G. W., Givens, J. R., Nicholson, W. E., and Island, D. P. (1965). The ectopic ACTH syndrome. Cancer Res., 25, 1057-1061.

${ }^{20}$ Munson, P. L., Tashjian, A. H., Jr., and Levine, L. (1965). Evidence for parathyroid hormone in nonparathyroid tumors associated with hypercalcemia. Ibid., 25, 1062-1067.

${ }^{21}$ Cunliffe, W. J., Black, M. M., Hall, R., Johnston, I. D. A., Hudgson, P., Shuster, S., Gudmundsson, T. V., Joplin, G. F., Williams, E. D., Woodhouse, N. J. Y., Galante, L., and MacIntyre, I. (1968). A calcitoninsecreting thyroid carcinoma. Lancet, 2, 63-66.

${ }^{22}$ Zollinger, R. M., Tomkins, R. K., Amerson, J. R., Endaho, G. L., Kraft, A. R., and Moore, F. T. (1968). Identification of the diarrheogenic hormone associated with non-beta islet cell tumors of the pancreas. Ann. Surg., 168, 502-521.

${ }^{23}$ Berdal, P., Braaten, M., Cappelen, C., Jr., Mylius, E. A., and Walaas, O. (1962). Noradrenaline-adrenaline producing nonchromaffin paraganglioma. Acta med. Scand., 172, 249-257.

${ }^{24}$ Oates, J. A., and Sjoerdsma, A. (1962). A unique syndrome associated with secretion of 5-hydroxytryphophan by metastatic gastric carcinoids. Amer. J. Med., 32, 333-342.

${ }^{25}$ Peart, W. S., Porter K. A., Robertson J. I. S., Sandler, M., and Baldock, E. 1963). Carcinoid syndrome due to pancreatic-duct neoplasm secreting 5-hydroxytryptophan and 5-hydroxytryptamine. Lancet, 1, $239-243$.

${ }^{26}$ Zeitlin, I. J., and Smith, A. N. (1966). 5-hydroxyindoles and kinins in the carcinoid and dumping syndromes. Ibid., 2, 986-991.

${ }^{27}$ McGavran, M. H., Unger, R. H., Recant, L., Folk, H. C., Kilo, C., and Levin, M. E. (1966). A glucagonsecreting alpha-cell carcinoma of the pancreas. New Engl. J. Med., 274, 1408-1413.

${ }^{28}$ Bower, B. F., and Mason, D. M. (1964). Measurement of antidiuretic activity in plasma and tumor in carcinoma of the lung with inappropriate antidiuresis. (Abstr.). Clin. Res., 12, 121.

${ }^{29}$ Yalow, R. S., and Berson, S. A. (1959). Assay of plasma insulin in human subjects by immunological methods. Nature (Lond.), 184, 1648-1649.

${ }^{30}$ Steigbigel, N. H., Oppenheim, J. J., Fishman, L. M., and Carbone, P. P. (1964). Metastatic embryonal carcinoma of the testis associated with elevated plasma TSH-like activity and hyperthyroidism. New Engl. J. Med., 271, 345-349.

${ }^{31}$ Glick, S. M., Roth, J., Yalow, R. S., and Berson, S. A. (1965). The regulation of growth hormone secretion. Recent Progr. Hormone Res., 21, 241-283.

${ }^{32}$ Sircus, W. (1964). Zollinger-Ellison syndrome. In Symposium on Advanced Medicine, Edited by N. Compston. Pitman, London.

${ }^{33}$ Kofstad, J., Frøyshov, I., Gjone, E., and Blix, S. (1967). Pancreatic tumor with intractable watery diarrhea, hypokalemia and hypercalcemia. Scand. J. Gastroent., 2, 246-250.

${ }^{34}$ Tracy, H. J., and Gregory, R. A. (1964). Physiological properties of a series of synthetic peptides structurally related to gastrin I. Nature (Lond.), 204, 935-938.

${ }^{35}$ Ballard, H. S., Frame, B., and Hartsock, R. J. (1964). Familial endocrine adenoma-peptic ulcer complex. Medicine (Baltimore), 43, 481-516.

${ }^{36}$ Wermer, P. (1954). Genetic aspects of adenomatosis of endocrine glands. Amer. J. Med., 16, 363-371.

${ }^{37}$ Christlieb, A. R., and Schuster, M. M. (1964). Zollinger-Ellison syndrome: a clinical appraisal based on a review of the literature. Arch. intem. Med., 114, 381-388.

${ }^{38}$ Solcia, E., Vassallo, G., and Capella, C. (1968). Selective staining of endocrine cells by basic dyes after acid hydrolysis. Stain Technol., 43, 257-263.

${ }^{39}$ Bloodworth, J. M. B., Jr., and Elliott, D. W. (1963). The histochemistry of pancreatic islet cell lesions. $J$. Amer. med. Ass., 183, 1011-1015.

${ }^{40}$ Lacy, P., and Williamson, J. R. (1960). Electron microscopic and fluorescent antibody studies of islet cell adenomas. (Abstr.). Anat. Rec., 136, 227-228.

${ }^{41}$ Carter, D., Coombes, M., Macleod, I. B., Thomson, C. G., and Sircus, W. (1969). Electronmicroscopy of disaggregated antral cells. (unpublished data).

${ }^{42}$ McGuigan, J. E. (1968). Gastric mucosal intracellular localisation of gastrin by immunofluorescence. Gastroenterology, 55, 315-327.

${ }^{43}$ Cleator, I. G. M., Coombes, M., Horn, D., Thomson, C. G., and Sircus, W. (1969). The presence of pancreatic and gastric secretagogues in extracts of an islet cell tumour of pancreas with choleraic diarrhoea and of a similar activity in the circulation of a second case. (In preparation).

"Brunt, P. W., Walker, R. J., Small, W. P., Falconer, C. W. A., and Sircus, W. (1969). Two cases of choleraic diarrhoea with special reference to exocrine hypersecretion of pancreas. (In preparation).

${ }^{45}$ McGuigan, J. E., and Trudeau, W. L. (1968). Immunochemical measurement of elevated levels of gastrin in the serum of patients with pancreatic tumors of the Zollinger-Ellison variety. New Engl. J. Med., 278, 1308-1313.

${ }^{4}$ Thomson, C. G., and Sircus, W. (1967). Experiences with a bioassay method for the diagnosis of the ZollingerEllison syndrome. (Abstr.). Gut, 8, 632 .

${ }^{4}$ Gregory, H., Hardy, P. M., Jones, D. S., Kenner, G. W., and Sheppard, R. C. (1964). The antral hormone gastrin: structure of gastrin. Nature (Lond.), 204, 931.

${ }^{48}$ Brown R. E., and Still, W. J. S. (1968). Nesidioblastosis and the Zollinger-Ellison syndrome. Amer. J. dig. Dis., 13, 656-663.

${ }^{49}$ Marks, I. N., Bank, S., and Louw, J. H. (1967). Islet cell tumor of the pancreas with reversible watery diarrhea and achlorhydria. Gastroenterology, 52, 695-708.

${ }^{{ }^{\circ} B}$ Brown, C. H., Neville, W. E., and Hazard, J. B. (1950). Islet-cell adenoma without hypoglycemia, causing duodenal obstruction. Surgery, 27, 616-620. 
${ }^{51}$ Mansbach, C. M., II, Wilkins, R. M., Dobbins, W. O., and Tyor, M. P. (1968). Intestinal mucosal function and structure in the steatorrhea of Zollinger-Ellison syndrome. Arch. intern, Med., 121, 487-494.

${ }^{52}$ James, A. H. (1964). Gastric epithelium in the duodenum. Gut, 5, 285-294.

${ }^{53}$ Polacek, M. A., and Ellison, E. H. (1966). Parietal cell mass and gastric acid secretion in the Zollinger-Ellison syndrome. Surgery, 60, 606-614.

${ }^{54}$ Crean G. P., Rumsey, D. R. E., and Sircus, W. (1964). Quoted Zollinger-Ellison syndrome. In Symposium on Advanced Medicine. Edited by N. Compston, Pitman, London.

${ }^{55}$ Yoshinaga, T., Okuno, G., Shinji, Y., Tsujii, T., and Nishikawa, M. (1966). Pancreatic A-cell tumor associated with severe diabetes mellitus. Diabetes, 15, 709-713.

${ }^{56}$ Lancet (1968). Leading article, Glucagon. 2, 1021-1022.

${ }^{5}$ Levin, M. E. (1968). Endocrine syndromes associated with pancreatic islet cell tumors. Med. Clin. N. Amer. 52, 295-312.

${ }^{58}$ Paloyan, E., Lawrence, A., Ernst, K., Worobec, R., Deininger, E., Paloyan, D., and Harper, P. V. (1966). Inter-relationships between parathyroids and islets of Langerhans. (Abstr.), Fed. Proc., $25,495$.

${ }^{59}$ Sagild, U., Andersen, V., and Andreasen, P. B. (1961). Glucose tolerance and insulin responsiveness in experimental potassium depletion. Acta med. Scand., 169, 243-251.

${ }^{60}$ Blair, E. L., Keenlyside, R. M., Newell, D. J., Reed, J. D., and Richardson, D. D. (1968). Assay of gastrin by means of its gastric acid stimulating activity. $J$. Physiol., 198, 613-626.

${ }^{61}$ Clemett, A. R., and Park, W. M. (1967). Arteriographic demonstration of pancreatic tumor in the ZollingerEllison syndrome. Radiology, 88, 32-34.

${ }^{62}$ Priest, W. M., and Alexander, M. K. (1957). Islet-cell tumour of the pancreas with peptic ulceration, diarrhoea, hypokalaemia. Lancet, 2, 1145-1147.

${ }^{63}$ Sayle, B. A., Lang, P. A., Green, W. O., Jr., Bosworth, W. C., and Gregory R. (1965). Cushing's syndrome due to islet cell carcinoma of the pancreas. Report of two cases: one with elevated 5-hydroxyindole acetic acid. Ann. intern. Med., 63, 58-68.

${ }^{64}$ Brown, P. W., Sircus, W., Smith, A. N. Donaldson, A. A., Dymock, I. W., Falconer, C. W. A., and Small, W. P. (1968). Scintillography in the diagnosis of pancreatic disease. Lancet, 1, 160-163.

${ }^{65}$ Melmed, R. N., Agnew, J. E., and Bouchier, I. A. D. (1968). The normal and abnormal pancreatic scan. Quart. J. Med., 37, 607-624.

${ }^{66}$ Ellison, E. H., and Wilson, S. D. (1964). The Zollinger-Ellison syndrome: Re-appraisal and evaluation of 260 registered cases. Ann. Surg., 160, 512-530. 